\title{
The Implementation of Good Corporate Governance to Develop Islamic Micro Insurance in Indonesia
}

\author{
Irman Firmansyah \\ Accounting Department, Economics Faculty, Siliwangi University, Tasikmalaya \\ email: irmanfirmansyah@unsil.ac.id \\ Abrista Devi \\ Islamic Economic Department, Ibn Khaldun University, Bogor \\ email:abristasmart@gmail.com
}

\begin{abstract}
At present Islamic micro insurance in Indonesia shows significant growth. Therefore, to maintain its existence, it must be supported by good governance. This study is aimed to find the best model in order to create Good Corporate Governance (GCG) for Islamic micro insurance development. The research methodology employed in this study was Analytic Network Process (ANP) using quantitative and qualitative approaches. The informants of this consist of practitioners, academia, and researchers who have good understanding of the problem. The finding of this study shows that the priority to embody good corporate governance principle in order to develop Islamic micro insurance in Indonesia namely, responsibilities, followed by equality and fairness, independences, accountability and transparency. In addition, the priorities of strategies that can be implemented to optimize GCG implementation are training and education for human resources, followed by focus on internal control mechanism, and the third is good corporate governance implementation in each level. The finding of this study also contributed to the best model of good corporate governance model to enhance Islamic micro insurance in Indonesia.
\end{abstract}

\section{Keywords:}

Good corporate governance, Islamic insurance, Islamic micro insurance, Analytic network process.

\section{INTRODUCTION}

Indonesia is a country which has a big potential market segment in Islamic economic considering Indonesia has the biggest Muslim population in the world. The growth of Islamic economic is featured by the growth of Islamic financial industry, both bank institutions and non-bank institutions. Islamic non-bank financial industry is becoming one pillar to give the financial services to the society in order to reach the welfare. However, the society's awareness to invest in financial industry is still low, especially in insurance product. Micro Insurance Development Team (OJK, 2013) revealed that a third of Indonesian population, or it's about 77 million people who don't have

IQTISHADIA 
IQTISHADIA

12,2

190

saving or insurance protection as protector when something bad happened. Most of Indonesian people argued that insurance is only reserved for middleup community. In addition, premium of insurance is also considered to be high as well as the lack of community knowledge about the importance of insurance make this kind of investment is not attractive to low-income community (kompasiana.com, 2015). Furthermore, Nuryartono (2013) stressed that two main causes of most Indonesia people do not have the insurance product because they do not have sufficient funds as well as they do not have proper information.

Indonesia Financial Services Authority (OJK) showed their support to enhance the growth of Islamic financial industry in Indonesia by forming Islamic micro insurance product which has been officially launched in 2014 . The special characteristic of Islamic micro insurance is not only reserved to low income people but also having the affordable premium. Microinsurance plays a significant role in the economic development of major Muslim countries. It was indicates from several empirical studies stated that insurance sectors as a provider of risk transfer on economic growth find a rather positive relationship (Erlbeck, Altuntas, \& Stolzle, 2011).

Islamic insurance industry is welcomed for the establishing of Islamic micro insurance product and evidenced through increasingly incessant of Islamic insurance companies in promoting Islamic micro insurance products. Therefore, in order to achieve the goal of Islamic insurance companies in socialize this product optimally, it needs to be followed by having good corporate governance. This statement also stressed by Chaudary (2014) where insurance company could be a good position to enhance the growth of economic and country development only in one condition, that the good corporate governance will create more employment opportunities, business support through accident claim payment, dividend payment to shareholders and earning more tax income to the government.

Study regarding to the insurance sector development and economic development in Nigeria revealed that the growth of insurance sector and development positively and significant affecting to the economic growth in a country (Oke, 2012). Therefore, we can conclude that corporate governance is not only important to the operating performance and firm's value, but also to the whole country at a macro level (Sapovadia, 2009). Therefore, it is required professionalism business management to pretend this product in market. Corporate failures have become a major issue with respect to the firms in developing and developed countries which has been attributed to 
the poor governance practices (Wanyama \& Olweny, 2013). Good corporate governance is being important for the organization, including insurance firms, culminates to higher firm's market value, lower cost of funds and higher profitability (Black, Jang, \& Kin, 2006; Claessens, 2006).

Until now, there has been no research that explains what aspects The Implementation of Good Corporate are important to be identified so that GCG can be applied to the Islamic microinsurance sector in Indonesia. Most researchers only test the factors that influence governance so it is difficult to apply in the practical world.

Therefore, In order to run the good corporate governance optimally in developing Islamic micro insurance, we need to identify clearly which good corporate governance principle aspect need to be prioritized and what factors need to be prioritized to run those principles. Therefore, to solve those problems are required some proper strategies through model formulation that can be implemented by the insurance companies to enhance the Islamic micro insurance product in Indonesia.

\section{LITERATUR REVIEW}

\section{Islamic Micro Insurance}

Micro insurance is insurance product reserved for low-income society, which has a simple feature \& administration, easy to find, affordable price, and immediately in claim payment. Micro insurance development is aimed to increase the number of low-income society in having insurance product as protection mechanism for their financial risk. In line with above definition, Hasim (2014) stated that microinsurance is a special category of insurance that provide protection to the poor. Yusuf and Mobolajo (2012) stated that microinsurance can be simply defined as "insurance for the poor", means that micro insurance are targeted for low-middle income people who less ability to pay the premium but highly need of insurance protection product, such as micro business, farmer, etc.

Churchill (2006) affirmed that the term of microinsurance refers to the two components which it consists of the part micro addresses the financial resources of the target group. Poor people or low-income households and their small enterprises deal only with small amounts of income, assets, premiums and benefits. The term of insurance indicates a financial service aiming at providing customers with compensations for adverse events through riskpooling. Therefore, micro insurance in Indonesia have many characteristics in line with the needs and the ability of low-income society, namely, simple, easy, economist, and immediately. 
IQTISHADIA

12,2

Micro insurance polis must be simple, straight, and understandable to low-education society with a few exceptions. Micro insurance product must be able to give the protection on the risk of losses or damages of a low value asset for the short term. Fund management for Islamic insurance company has been regulated by fatwa DSN-MUI (Dewan Syariah Nasional - Majelis Ulama Indonesia) Fatwa DSN No.21/DSN-MUI/X/2001. Fund management must be avoided from gharar (fraud), riba (interest), zhulm (persecution), risywah (extortion), forbidden goods and ma'siat (immoral). From those both of insurance variance, this paper is officially discussed Islamic micro insurance subject.

\section{Good Corporate Governance in Insurance Company}

Good corporate governance can be simply defined as a regulation and control system for company to create value added to all stakeholders. According to OECD (1999), good corporate governance is a system where Business Company is directed to be controllable. Good corporate governance company structure determine the rights and responsibilities distribution among different level of members in a company, such as board management, managers, shareholders, and others stakeholders. In addition, it also determines the regulation and procedure in decision making regarding to company problems. Organisation for Economic Co-operation and Development (OECD) stated that good corporate governance principle must be able to recognize the rights of stakeholders and ensure the disclosure and transparency on time and accurate regarding to all corporate material. Good corporate governance must ensure the strategic direction from its company, effective management monitoring by the board of management and board of management accountability (Hafeez, 2013). According to Financial Service Authority Regulation number 73/POJK.05/2016 that there are five (5) principles of good corporate governance for insurance company, namely, (1) transparency, (2) accountability, (3) responsibility, (4) independency, (5) fairness.

Corporate governance structure prompts worth business segment proficiencies, progress, business and fiscal change. This recommends that if affiliations have unbelievable governance drills, they will pull in quality and responsibility financing to help handle research and help change which will as necessities in order to upgrade the financial markets (Bernal \& Lubrano, 2007; Cremers \& Nair, 2005). In addition, the benefits of good corporate governance practices in a company are included: increasing the company 
valuation and increasing the profitability (Gompers, Ishii, \& Metrick, 2003); facilitating the bigger access to financing, decreasing the capital cost, better performance and good treatment to all stakeholders (Claessens, Djankov, \& Fan, 2002); and promoting a better information disclosure in business report in order to make easier market liquidity and better capital formulation (Frost, Gordon, \& Hayes, 2002). Yusuf and Mobolajo (2012) also stressed that the critical success factors of Islamic micro insurance as the product of micro finance is good governance practices and transparency. Transparency is being the important matter considering Indonesian people are having the lack of trust to insurance company.

Some studies have been conducted regarding to the good corporate governance, one of them study by Fadun (2013) examined the effect of good corporate governance implementation to company performance of Nigerian Stock Exchange. The result obtained is stressing on how importance of good corporate governance structure in Nigeria insurance company. This study contributed to the problem decomposition into two aspects: first, giving the strong and simple understanding regarding to the effect of good corporate governance to company performance; second, filling up the knowledge gap because of lack of study conducted. Subsequently, Fadun (2013a) conducted another study related to the development of insurance company in Nigeria. Survey is conducted to 112 respondents. The result of this study stated that to grow a company is needed a good corporate governance professionalism in order to promote insurance company which is supplied with the effectiveness of risk management.

Another study was conducted by Najjar (2012) by examining the research for insurance company in Bahrain Stock Exchange within the year 2005-2010. The result of this study concluded that there is a significant effect of good corporate governance to the company performance in Bahrain insurance industry. Gabasi, Kertahadi and Firdausi (2014) is conducted the study regarding to the practice of good corporate governance for oil and gas company in Libya. The result concluded that the good corporate governance practice is playing an important role in order to obtain company's financial performance. Dominic and Memba (2015) are conducted the study in 26 companies which are registered in Nairobi Securities Exchange. The result showed that if a company implements good corporate governance then it will able to increase the company's financial performance.

Regarding to some results of literature review as mentioned above, we can conclude that good corporate governance is required to minimize business 
IQTISHADIA

12,2

194

risk as well as to increase the business performance. Mehta (2006) stated that corporate governance moreover upsurges reliability, accountability, and predictability of decision-making. According to Bansal and Bansal (2014) that every company is following corporate governance norms in one or the different manner according to the laws, guidelines, code of ethics, corporate social responsibility prevalent in the country.

The above studies explain the importance of implementing good governance not only for Islamic insurance but for all types of business institutions. Basically the research explains the importance of implementing GCG for businesses because it will improve performance.

Related to the development of Islamic microinsurance in Indonesia, it is necessary to develop a research model on solutions and strategies on good governance of Islamic microinsurance through various studies including literature and field studies. The basis for implementing governance can be from the OECD, and in Indonesia there are specific regulations regarding the application of GCG for insurance namely the regulation of Financial Services Authority POJK Number 73/POJK.05/2016. Therefore, this research will build a GCG implementation model for microinsurance based on OECD and regulation of Financial Services Authority POJK Number 73/POJK.05/2016.

\section{RESEARCH METHOD}

The methodology obtained in this study is qualitative and quantitative approach using Analytic Network Process (ANP) which was developed by Thomas L Saaty and Louwis S. Vargas. Data used in this study is primary data which is obtained from in-depth interview to some experts, practitioners, academia and researchers, who have good understanding about the problems observed (good corporate governance management of insurance company focus on Islamic micro insurance product). After in-depth interview process is conducted, then followed by model decomposition and validated by one of respondent who considered the most competent respondent among others. After validating the model, the model is poured into the software in order to create the pair-wise comparison questionnaire. The questionnaires then filled by all respondents to obtain the priority of each aspect in the model.

The respondents are chosen accidently by considering their understanding about the problems of good corporate governance of Islamic insurance company which has Islamic micro insurance product. The numbers of respondents in this study are five respondents consist of three respondents from practitioners of Islamic micro insurance and two respondents from 
academia and one respondent as researcher. ANP methodology does not requirea large number of respondents, unless the respondent must be expert in the area of study. If there are too many respondents but they are not experts, the results of the study are not good. The question of ANP questionnaire is pair-wise comparison among elements in a cluster to find out which element between them has the greater impact and how big the differences seen from one side. Numeric scale from 1-9 is used as a translation from verbal valuation.

The fundamental scale of values to represent the intensities of judgments is shown in Table 1. This scale has been derived through stimulus response theory and validated for effectiveness, not only in many applications by a number of people, but also through theoretical justification of what scale one must use in the comparison of homogeneous elements (Saaty \& Vargas, 2006).

Tabel 1: The Fundamental Scale of Absolute Numbers

\begin{tabular}{|c|c|c|}
\hline & $\begin{array}{l}\text { nsity of Defnition } \\
\text { Importance }\end{array}$ & Explanation \\
\hline 1 & Equal Importance & $\begin{array}{l}\text { Two activities contribute equally } \\
\text { to the objective }\end{array}$ \\
\hline 2 & Weak & \\
\hline 3 & Moderate importance & $\begin{array}{l}\text { Experience and judgment slightly } \\
\text { favor one activity over another }\end{array}$ \\
\hline 4 & Moderate plus & \\
\hline 5 & Strong importance & $\begin{array}{l}\text { Experience and judgment strongly } \\
\text { favor one activity over another }\end{array}$ \\
\hline 6 & Strong plus & \\
\hline 7 & $\begin{array}{l}\text { Very strong or } \\
\text { Demonstrated }\end{array}$ & $\begin{array}{l}\text { An activity is favored very strongly } \\
\text { over another; its dominance } \\
\text { demonstrated in practice }\end{array}$ \\
\hline 8 & Very, very strong & \\
\hline 9 & Extreme importance & $\begin{array}{l}\text { The evidence favoring one activity } \\
\text { over another is of the highest } \\
\text { possible order of affirmation }\end{array}$ \\
\hline
\end{tabular}

Source: (Firmansyah \& Devi, 2017; Saaty \& Vargas, 2006)

The questionnaire filled by respondents must be accompanied by the researcher to keep the consistency from the given answer. Generally, the pair-wise comparison question in ANP questionnaire has a large number, then non technical factors also could affect to the inconsistency. 
IQTISHADIA

12,2

The data which is obtained from this study will be analyzed by ANP methodology. ANP is a methodology that commonly used in various qualitative studies, such as decision making, forecasting, evaluating, mapping, strategizing, resources allocating, etc. There are three main function of ANP methodology, as follows:

1. Model Construction is constructing ANP model based on theoretical and empirical literature reviews of the problem, open questionnaires are asked to practitioners from various experts from various practitioners, academia, and researcher. Follow-up is conducted through in-depth interviews to garner more detailed information to be able to comprehend the real problems.

2. Model Quantification is quantifying and measuring the ANP model or network, pair-wise questionnaires are drawn based on final ANP network designed in line with model construction, which has been automatically formed in super decisions software. In order to ensure that the questionnaires are worked effectively within allowable inconsistency, questionnaire testing is conducted to respondents. In this step, modification to questionnaires might be needed to improve effectiveness to gather appropriate data (Ascarya, 2011).

3. Model Quantification. The results or synthesis of ANP network in super decisions software for each respondent can be generated. The data are then exported to excel worksheet to be manipulated to produce the desired outputs. To produce scientific 'consensus' results, geometric means of all respondents' responses are calculated, re-inputted to ANP network in super decisions software and re-synthesized. This is the formula of Geometric Mean (Ascarya, 2011):

$$
\left(\prod_{i}^{n}=1 a_{i}\right)^{1 / n}=\sqrt[n]{a_{1}} a_{2 . . .} a_{n}
$$

To measure the approval level of respondents' answers (R1-Rn) then use rater agreement by Kendall's Coefficient of Concordance (W;0 $<\mathrm{W} \leq 1)$. To calculated Kendall's (W), the first is to rank every answer then sum it up.

$$
R_{i}=\sum_{j}^{m}=1 r_{i, j}
$$

The average value of the total ranking is:

(3) $\quad R=\frac{1}{2} m(n+1)$

The sum of squares deviation (S), calculated by the formula:

$$
S=\sum_{i}^{n}=\mathbf{1}\left(\boldsymbol{R}_{i}-\bar{R}\right)^{2}
$$

So obtained Kendall's W, namely

$$
W=\frac{12 S}{m^{2}\left(n^{3}-n\right)}
$$




\section{RESULTS}

According to the result of problem decomposition through literature review and in-depth interviewto several respondents who have better understanding about Islamic micro insurance \& good corporate governance in Indonesia, it is obtained some strategies and the priorities of good corporate governance practices. Good corporate governance model is basically taken from OECD and regulation of Financial Services Authority POJK Number 73/POJK.05/2016. Next step, we formed ANP model to find the most important priorities in optimizing Islamic insurance good corporate governance in Indonesia. The ANP model and the connection can be seen as follow:

\section{Figure 1: ANP Model in Super Decision Software}

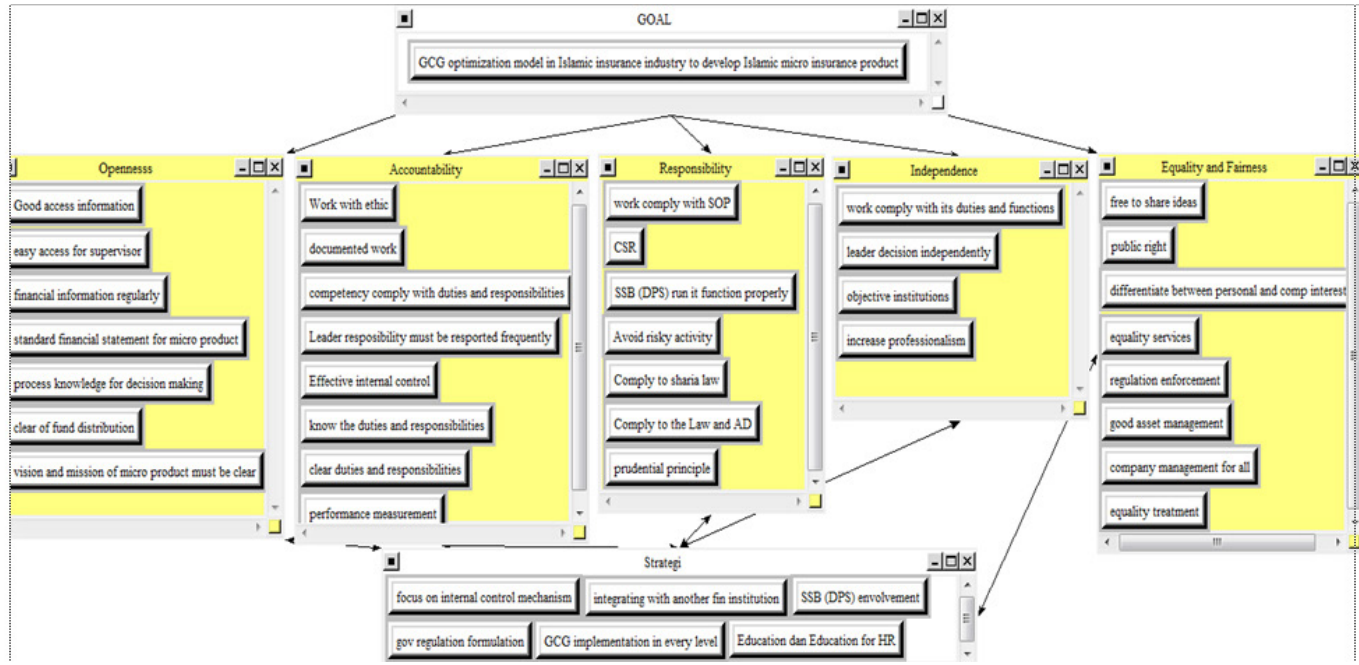

From the model in figure 1 above, next step is quantification the data using questionnaire instrument. Data which is obtained from questionnaire will be analyzed by super decision software to identify the most priorities aspect.

Transparency aspect include of (1) information provision access regarding to Islamic micro insurance \& good corporate governance; (2) supervisor has an easy access to the internal company; (3) financial information must be made in time and relevant (routine); (4) financial report regarding to Islamic micro insurance product must be made relevant with accounting standard; (5) all parties (internal and external parties) must know the decision making process; (6) the distribution of investment fund must be clear and easy access by the society; (7) the company vision, mission, purposes, and goal in order to develop Islamic micro insurance product must be stated clearly. The assessment of priority result of the respondents can be seen in the figure 2.
Implementation of Good Corporate 
IQTISHADIA

12,2

Description:

$\mathrm{R}=$ Respondent, GEOMEAN $=$ Mean value of all respondents

Figure 2 shows us that the top three main priority of element from transparency aspect, namely regular financial information, followed by financial report of micro product must be standardized, and the third priority is easy access of supervision. In addition, financial information must be published regularly, so that it can be easily access by everyone in every time.

Accountability aspects consist of eight aspects, there are (1) details organ duties and responsibilities must be clear; (2) organ competence must be suitable with duties and responsibilities; (3) effective internal control; (4) the existence of performance measurement to all level of organ; (5) organ must work with Islamic business ethic; (6) all organ know their roles, duties and responsibilities; (7) leaders accountability must be reported regularly; and (8) work documented and carefully preserved. Valuation result of the respondents could be seen from the following figure 3 :

Figure 3: Prioritization Result of Accountability Aspect

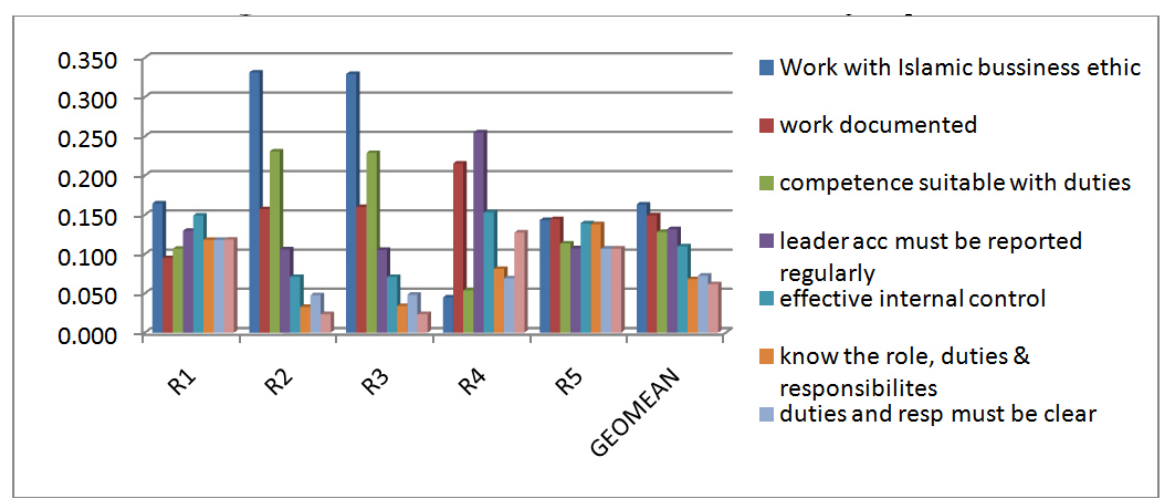

Description:

$\mathrm{R}=$ Respondent, GEOMEAN $=$ Mean value of all respondents 
Figure 3 shows us that the main priority element in accountability aspects are work with Islamic business ethic, followed by work documented and carefully preserved and the third priority is leader accountability must be reported regularly.

Responsibilities aspect consist of (1) all organ must work with prudential principle; (2) comply with the law and article of association; (3) comply with Islamic regulation; (4) implement social responsibility to society and environment; (5) organ must work comply to the standard operational procedure; (6) company must avoid the risky activity; and (7) Sharia Supervisory Board run its function properly. Valuation result of the respondents could be seen from the following figure 4:

\section{Figure 4: Prioritization Result of Accountability Aspect}

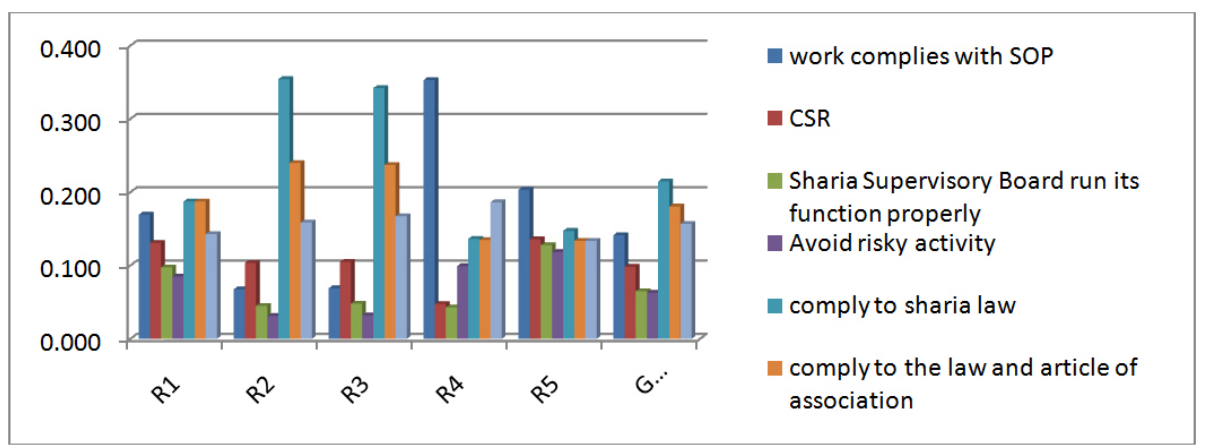

Description:

$\mathrm{R}=$ Respondent, GEOMEAN $=$ Mean value of all respondents

Figure 4 above shows that the main priority of responsibilities aspect are comply with the sharia law, followed by comply with the law and article of association, and the third priority is prudential principle.

Independency aspects consist of (1) the institution is free from any interest and work with objective; (2) continue to improve the professionalism; (3) organ work comply with its duties and function, not dominate and throw the responsibilities to other parties; (4) leader decision is free from other parties interest in order to avoid from company risk. Valuation result of the respondents could be seen from the following figure 5: 
IQTISHADIA

12,2

200
Figure 5: Prioritization Result of Independency Aspect

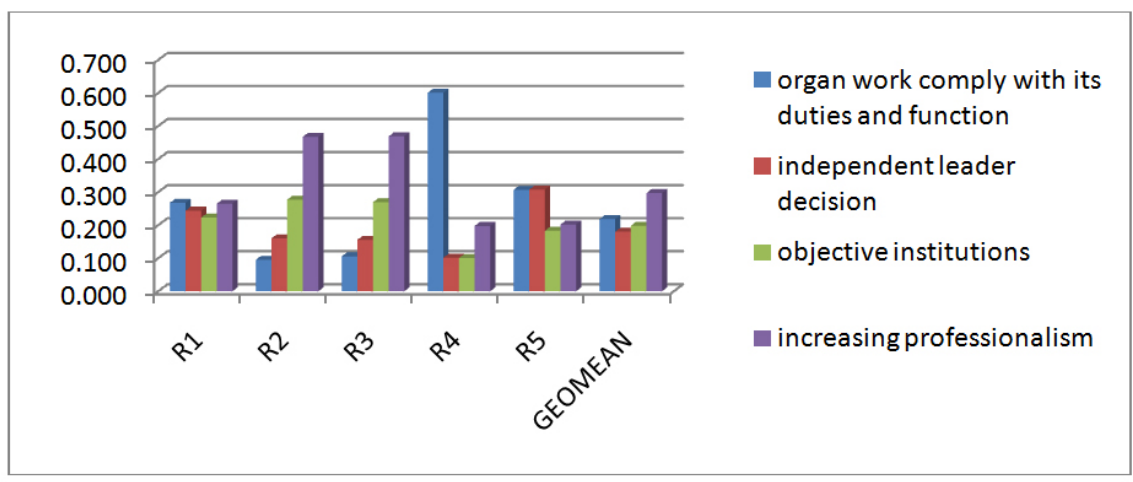

Description:

$\mathrm{R}=$ Respondent, GEOMEAN = Mean value of all respondents

Figure 5 shows us that the most priority element in of independency aspect is increasing professionalism, followed by working comply with its duties and functions, and the third priority is the institutions must be free from any interest and work objectively.

\section{Equality and Fairness Aspect}

Equality and fairness aspect are consist of (1) the right of polis-holder must be clear; (2) there must be regulation enforcement to protect members from fraud; (3) company asset management must be better and prudent; (4) allow polis-holder to share their idea and argument freely; (5) equality treatment to all organ and society without discriminate the tribe, religion, race, gender, and physical condition; (6) equality services to all polis-holder of Islamic micro insurance and public; (7) all organ can differentiate between company interest and personal interest; (8) company management for all stakeholders. Valuation result of the respondents could be seen from the following figure 6:

\section{Figure 6: Prioritization Result of Equality and Fairness Aspect}

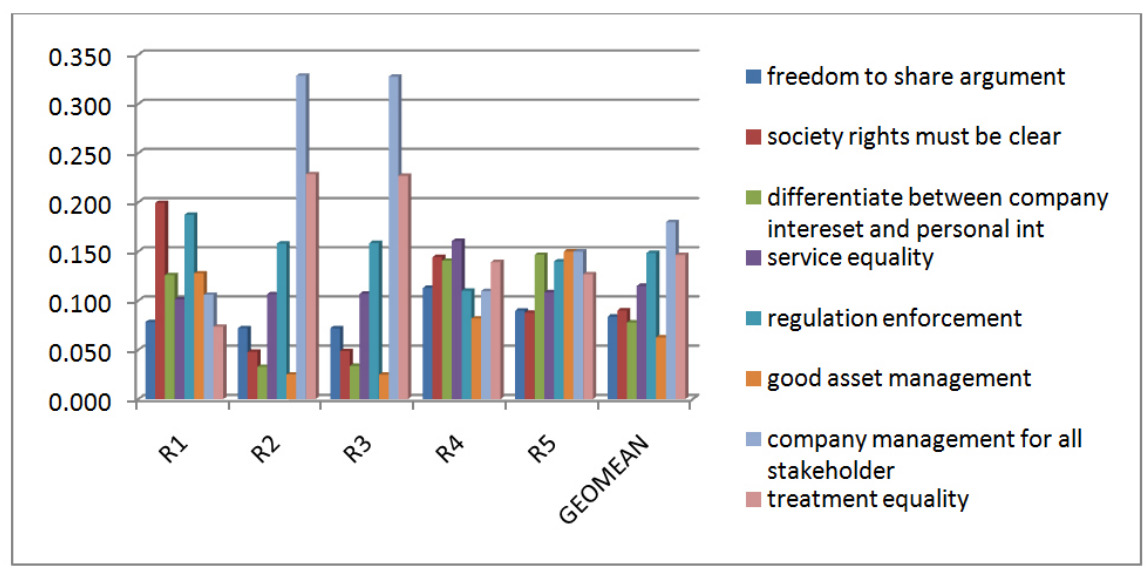

Description:

$\mathrm{R}=$ Respondent, GEOMEAN = Mean value of all respondents 
Figure 6 describes the main priority element of equality and fairness aspect is company management for all stakeholders, and followed by regulation enforcement, and the third priority is equal treatment to all polisholder of Islamic micro insurance and public society.

From five GCG principles of Islamic micro insurance as already mentioned above, the finding of this research also found the priority of principle implementation and it will became the important priority by insurance company.

Figure 7: The Priority of GCG Principle Implementation for Islamic Micro Insurance

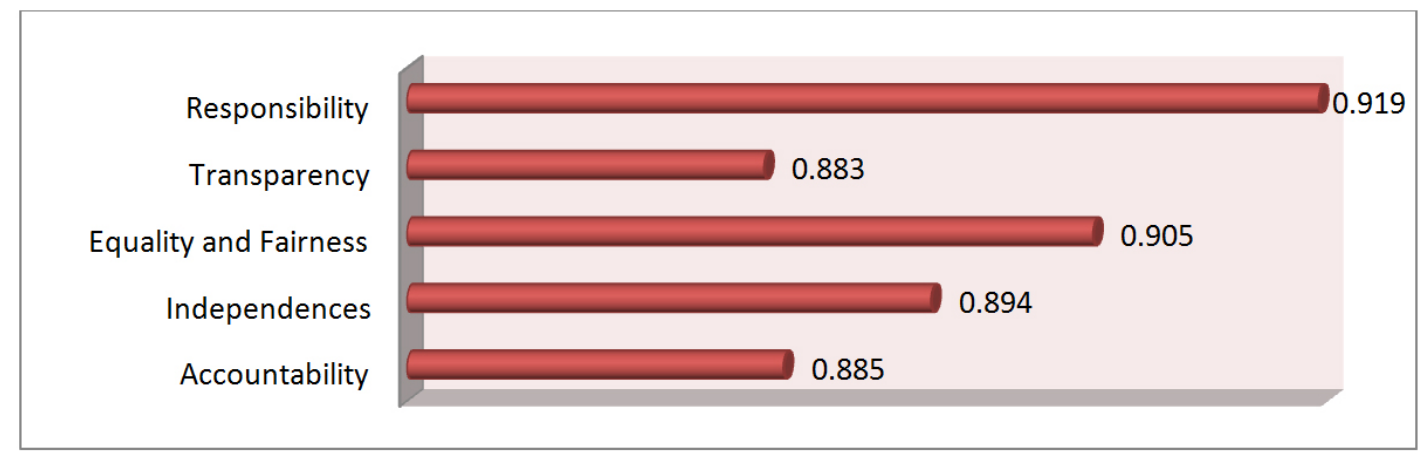

Regarding to figure 7 can be seen that the main priorities in good corporate governance implementation as follow:

1. Responsibilities principle

2. Equality and fairness principle

3. Independence principle

4. Accountability principle

5. Transparency principle

Those priorities is being important to the company that will implement good corporate governance especially in developing Islamic micro insurance, because those priorities will be the implementation model of optimal good corporate governance.

\section{Strategies}

In order to establish good corporate governance in Islamic insurance industry, there are eight strategies that can be undertaken, namely: (1) focus on internal control mechanism; (2) good corporate governance implementation in every organizational level; (3) the involvement of DPS in implementing the prudential principles; (4) training and education to Human Resource; (5) 
IQTISHADIA

12,2

good integration with another financial institutions; (6) government policy formulation. Valuation result of the respondents could be seen from the following figure 8:

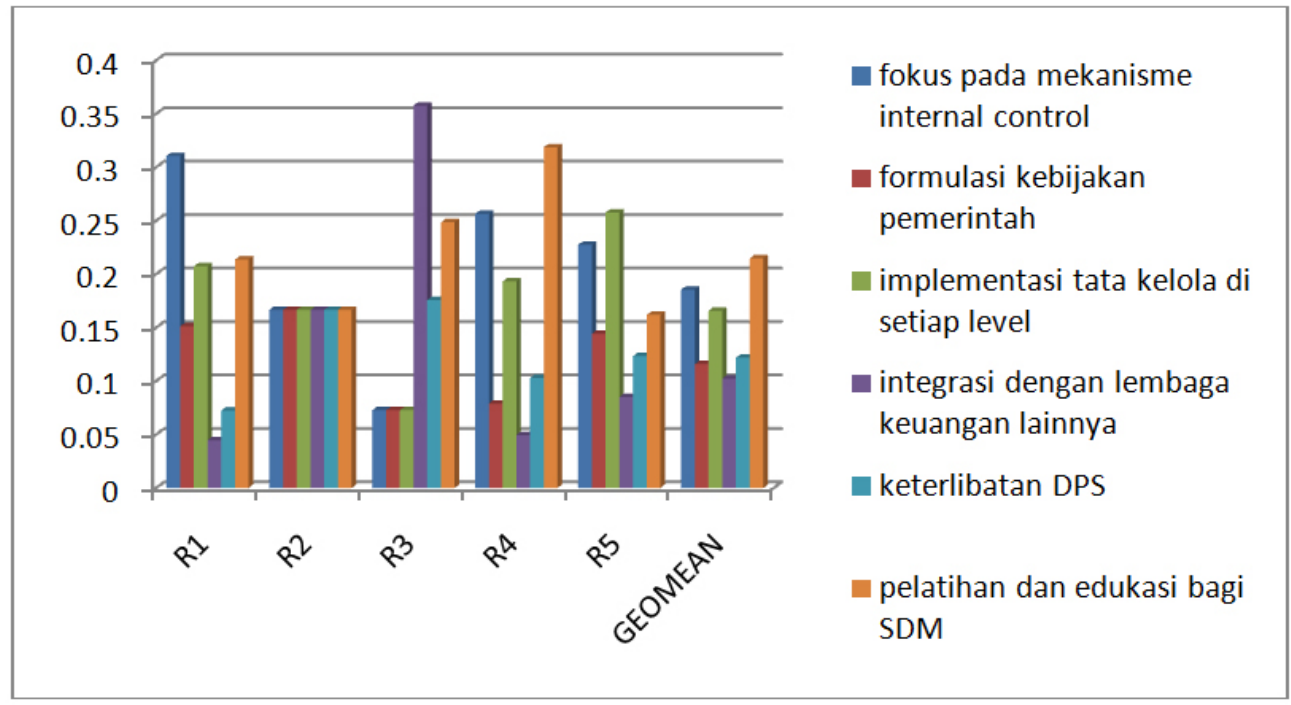

Description:

$\mathrm{R}=$ Respondent, GEOMEAN = Mean value of all respondents

Figure 8 shows us that the most priority of strategies element to optimize the implementation of Good Corporate Governance in Islamic micro insurance industry is training and education for human resource, followed by focus on internal control mechanism, and the third priority is good corporate governance implementation for each level organization.

\section{DISCUSSION}

The finding of this study regarding to the openness principle show that the main priority is financial information regularly, followed by the financial report of micro insurance product must be standardized and the last priority is easy access for supervision. This matter obviously reflects the limitation of financial information from Islamic Micro finance institutions such as BMT \& Islamic cooperation. The difficulty of accessing the financial report from Islamic micro finance institutions is being one problem to develop Islamic micro finance in Indonesia. This problem not only faced by Islamic micro finance but also other philanthropy institutions such as zakah and waqf institutions had limited in terms of financial report information. It is indicated through not all financial information of zakah institution can be 
easily access by online and regularly. This problem should be able to be critical attention to Islamic insurance industry which begun to target micro market to enhance financial inclusion in Indonesia. Officially, micro financial market is not being a new issue anymore in Indonesia, but this market is being more strategies considering the amount if micro, small and medium business in Indonesia is greater than macro business. Therefore, the need for financial institutions that can also serve micro people is getting bigger. The lack of society literacy and the less of socialization from the industry and government regarding to micro insurance also underlie the importance of financial information regularly in order to obtain the public trust about micro finance to use Islamic micro insurance product safely and comfortable.

The main priority of accountability principle is work with ethic, followed by work documentation, and the last priority is leader responsibility report must be reported regularly. Work with Islamic business ethic is being a special characteristic from the sharia compliance in accountability principles. In Islam, the clear of function, structure, system and responsibility of any level organ of the company are based on the employee capability to work with full ethic. It means that there is honesty in every work done, full of trustful in running any undertaken work, and absolutely need to present the Islamic business ethic in running any undertaken work. Therefore, the accountability function can be fulfilled in a firm to reach good corporate governance.

Islamic micro insurance is an insurance product that specialized to low-middle income society. The implementation of accountability aspect in Islamic insurance industry to develop Islamic micro insurance market share obviously reserved to keep the right of shareholder by ensuring the shareholder could get right, accurate, and just in time information. In addition, the implementation of accountability also keeps the continuous of company responsibility to make disclosure report accountable to all company stakeholders.

The covered risk must be balanced with the paid premium of members, but considering of Islamic micro insurance product has an affordable price, small size of market will give the higher risk to Islamic insurance industry. Therefore, in this condition where market size of Islamic micro insurance not as big as another insurance product, Islamic insurance company need to ensure the accountability aspect intensive and running properly, especially to the work documented and accountability report from the leader must be reported regularly. This matter obviously to maintain the investor trust as 
IQTISHADIA

12,2

204

well as shareholders who firstly funded Islamic micro insurance product before achieving the expected market size of this product.

The main priority of responsibility principle is sharia compliance, followed by comply with Indonesia law, and the last priority is prudential principles. This result is in line with the priority element of previous aspect (transparency and accountability) where sharia compliance element as the main element to be considered properly by the Islamic insurance industry. This matter is certainly became the main responsibility form for Islamic insurance industry to ensure all procedure of Islamic micro insurance product must comply with Islamic principles. The procedure is starting with product socialization, product marketing, followed by customer decision making represented by paid premium, premium fund management by separating into tabarru' fund through halal investment, claim payment to members, etc, where all those process must be sharia compliance.

Islamic micro insurance product not only must be sharia compliance, but Islamic insurance industry also must be able to ensure this product is not against the positive law and article of company association. The fulfillment of criteria which is appropriate with Islamic law and positive law, it will protect customer rights to use Islamic micro insurance product. The protected of customer rights certainly will affect to the customer secure and comfortable in using the Islamic micro insurance product, especially for long term.

The main priority of independence principle is increasing professionalism, followed by work comply with duties and function, and the last priority is free from any interest and work objectively. Islamic micro insurance product is new product if compared with another insurance product. The existence of Islamic micro insurance product as a strong commitment from Islamic insurance industry, which is not only make middle-up income people as market target insurance product and being a secondary market, but also can be reached by low income people. Therefore, it needs a high commitment from Islamic insurance industry to give the service in the form of Islamic micro insurance through their protection program. This matter obviously in-line with the finding of this research that the main important element in independency aspect is working professionally.

Professional is defined as someone attitude which is considered to have an ability and expertise in current field. Professional also can be defined as hard working, discipline, honest, high loyalty, and having high dedication to achieve the goal of company. Professionalism is not only measured 
by achieving the last result, but also measured by the process of work. Professional work process might obtain a good result. Being professional in Islamic insurance industry to develop Islamic micro insurance product is required through the process of work. Professional has the same meaning with commitment, it means that Islamic insurance have been committed to be professional in marketing and socializing Islamic micro insurance product honestly and accountability. They need to disclosure clearly the paid premium and claim fund received by members. They are also committing to be professional in fund management of micro insurance and ensure the eases of members while proffering the claim. Big market size is being a min target if Islamic micro insurance product would be profitable. Therefore, the level of professionalism must be increased and pretended by Islamic insurance industry in Indonesia.

The main priority of equality and fairness principle is company management for all stakeholders, followed by regulation enforcement, and the third priority is the same treatment to all polis holders of Islamic micro insurance and public. Islamic insurance basic principle is ta'awaun (helping each other). Therefore, the most priority principle and need to be considered in equality and fairness aspect is Islamic insurance company is managed for all interest, not only addressed to owner interest, but also to all Islamic insurance stakeholder interest. Along with the purpose of Islamic insurance itself, the goal of Islamic micro insurance product is also addressed to help among society especially to low income society with the affordable premium. This matter obviously became the commitment of Islamic insurance industry in order to give maximum service to the biggest market in Indonesia (micro market). Basically, Islamic insurance basic concept should be intelligible by all stakeholders include members and prospective members. If it is compared to conventional insurance, Islamic insurance has helping each other principle, therefore, the premium paid will be collected into tabarru' fund after spent for the cost of services and investment (if any) and it will be distributed to the members who have suffered their life or their wealth.

The lack of Islamic insurance iteration for low income society become a reason where Islamic insurance company need an extra work to educate people about Islamic insurance, especially Islamic micro insurance product. In order to support the existence of a sense of belonging and togetherness, especially in Islamic insurance management, it is required the support from regulator (in this case, government) to protect members from fraud. Not only Islamic insurance industry role, government also has the important 
IQTISHADIA

12,2

206

role through their regulation to establish friendly Islamic micro insurance product, and keep the right and obligation of polis-holder. The lack of public knowledge about Islamic insurance is extremely vulnerable to fluctuations degree of public trust toward this product. Therefore, Islamic insurance industry is required to have the important duties to maintain and keep the public trust (far from fraud) through the policies that stand for polis-holders.

The following strategies can be used to achieve good corporate governance of Islamic micro insurance is training and education for human resources, followed by focus on internal control mechanism, and the third is good corporate governance implementation in each level. According to the indepth interview result of one Islamic insurance practitioner, the main problem of Islamic insurance development especially for micro insurance product is the lack of qualified human resource who understands about Islamic micro insurance, while, instead of product quality obviously must be followed by detail understanding about the product and its sharia compliance. Therefore, this discussion is in-line with overall result of informant answer which is obtained that training and education for human resource is being the main important aspect to develop Islamic micro insurance product trough good corporate governance. The finding of this study is also in-line with previous study by Yusuf and Mobolajo (2012) stated that the critical success factors of Islamic micro insurance developing is continuous staff training.

In addition, the next most important strategy is focus on internal control mechanism and good corporate governance implementation in each level of organization. Both strategies are internal party's commitment (in this case is: Islamic insurance management) in order to establish the good corporate governance in each level organization for Islamic insurance. The form of internal control may involve the Islamic Supervisory Board (DPS) as supervisor for sharia compliance of Islamic micro insurance product, this matter obviously as a form to establish of halal product as well as halal implementation process. Sharia supervisory board involvement was the forth priority in Islamic micro insurance product development strategy through good corporate governance. Regulator involvement (in this case: sharia supervisory board) is also being a main concern of the previous study by Hasim (2014) where the Islamic micro insurance development is required well-developed institutional arrangements at least between four participants, there are, government, micro insurance operators or institutions, zakat funds, Non Government organizations, and micro insurance participants. 
If abovestrategies can be priorities and main concern for all stakeholders, not only for Islamic insurance management but also government role through synergy with another Islamic financial institution. Therefore, Islamic micro insurance product is suggested to do market penetration in the sort term, so it will increase public welfare through financial protection from Islamic micro insurance product. So that this research also supports research Chaudary (2014) that the implementation of good governance for insurance companies can encourage increased economic growth and country development

\section{CONCLUSION}

According to the results of this study, this study concludes that the model of Good Corporate Governance optimization for Islamic microinsurance is based on five principles of good corporate governance with priority rankings namely, responsibility, equality and fairness, independence, accountability, and transparency. The principle of responsibility can be achieved by complying with Islamic principles, followed by complying with the law and the articles of association, and working with the precautionary principle. The principle of equality and fairness can be achieved by way of corporate management directed to all interests, followed by enforcement of regulations, and equal treatment for all sharia and public micro insurance policy holders. The principle of independence can be achieved by increasing professionalism, followed by work in accordance with duties and functions, and the institution is free from interests and works objectively. The principle of accountability can be achieved by working with ethics, followed by documented results of work, and leaders' responsibilities must be reported frequently. The principle of transparency can be achieved through the provision of regular financial information, followed by financial information that micro products must be standardized, and easy access for supervisors.

While the strategies that can be used to achieve good corporate governance from Islamic microinsurance are training and education for human resources, followed by a focus on internal control mechanisms, and the third is the application of good corporate governance at every level

The findings of this study try to help insurance industry in owning good corporate governance especially related to the development of Islamic micro insurance product. Therefore, the existence of Islamic micro insurance product in current company can develop. The companies with a good corporate governance implementation will accept good response from 
IQTISHADIA

12,2

208

society, because they trust to the Islamic micro insurance management. In addition, the government also very assisted by the company who implement good corporate governance because will attract investor to invest in existing company. This condition obviously will increase government income indirectly especially from tax sector. Other implications are growing the trust of micro business to Islamic insurance industry on invested fund through Islamic micro insurance product in order to minimize risk the wealth owned. Therefore, micro business has a proper media if they want to invest in a company with Islamic concept.

\section{References}

Ascarya. (2011). The Persistence of Low Profit and Loss Sharing Financing in Islamic Banking: The Case of Indonesia. Review of Indonesian Economic and Business Studies1. LIPI Economic Research Center.

Bansal, B., \& Bansal, A. (2014). Corporate Governance and Risk Management in Insurance Sector: A Review of Literatur. International Journal of Scientific and Research Publication, 4(10).

Bernal, A., \& Lubrano. (2007). Growth, Financing, and Corporate Governance. International Finance Corporation World Bank Group Working Paper.

Black, B. ., Jang, H., \& Kin, W. (2006). Does corporate governance predict firms' market values? Evidence from Korea.Journal of Law, Economics and Organization, 22(2): 3-13.

Chaudary, P.(2014). Corporate Governancein InsuranceSector.International Journal of Research in Economics \& Social Sciences, 4(1). Retrieved from http://www.euroasiapub.org

Churchill, C. (2006). What is Insurance for the Poor? In C. Churchill (Ed.), Protecting the Poor. In A Microinsurance compendium. Geneva (pp. 25-44).

Claessens, S. (2006). Corporate governance and development. The World Bank Research Observer, 21(1): 91-122.

Claessens, S., Djankov, S., \& Fan, J. P. . (2002). Disentangling the incentive and entrenchment effects of large shareholders. The Journal of Finance, 57(6): 2741-2771.

Cremers, K. J. M., \& Nair, V. B. (2005). Governance mechanisms and equity prices. Journal of Finance, 6o(6): 2859-2894.

Dominic, O., \& Memba, F. (2015). Effect of Corporate Governance Practice on Financial Performance of Public Limited Companies in Kenya. 
International Journal of Management and Commerce Innovations, 3(1): 122-132.

Erlbeck, A., Altuntas, M., \& Stolzle, T. R. . (2011). Microtakaful: Field Study Implementation Evidence and Conceptual Issues. In Conference paper. Retrieved from www.rug.nl

Fadun, O. S. (2013a). Corporate Governance and Insurance Company Growth: Challenges and Opportunities. International Journal of Academic Research in Economics and Management Sciences, 2(1).

Fadun, O. S. (2013b). Corporate Governance and Insurance Firms Performance: Empirical Study of Nigerian Experience. Journal of Insurance Law \& Practice, 3(1).

Firmansyah, I., \& Devi, A. (2017). The Implementation Strategies of Good Corporate Governance for Zakat Institutions in Indonesia. International Journal of Zakat, 2(2): 85-97.

Frost, C. A., Gordon, E. A., \& Hayes, A. F. (2002). Stock exchange disclosure and market liquidity: An analysis of 50 international exchanges. Retrieved from http://www.ksri.org/bbs/files/researcho2/SSRN ID355361_codeo2

Gabasi, A. H. B. E., Kertahadi, \& Firdausi, N. (2014). An Analysis of Corporate Governance and Its Impact on the Firm's Financial Performance in Libya. IOSR Journal of Business and Management, 16(7): 61-70.

Gompers, P. A., Ishii, J. L., \& Metrick, A. (2003). Corporate governance and equity prices. Quarterly Journal of Economics, 118(1): 107-155.

Hafeez, M. M. (2013). An Analysis of Corporate Governance in Islamic and Western Perspective. International Journal of Business, Economic and Law, 2(3): 98-103.

Hasim, H. M. (2014). Developing a Conceptual Framework of Microtakaful as a Strategy towards Poverty Alleviation. Journal of Economics and Sustainable Development, 5(28): 1-9.

Mehta, D. M. (2006). Good governance. Encyclopedia of Governance. Sage Publications, Inc.

Najjar, N. (2012). The Impact of Corporate Governance on the Insurance Firm's Performance in Bahrain. International Journal of Learning \& Development, 2(2): 1-17.

Nuryartono, N. (2013). Micro Insurance Stakeholders in Indonesia Baseline Survey. Bogor Agriculture Institute, Research Corporation between US AID and SEADI. 
IQTISHADIA

12,2

Oke, M. O. (2012). Insurance sector development and economic growth in Nigeria. African Journal of Business Management, 6(23).

Saaty, T. L., \& Vargas, L. . (2006). Decision Making with the Analytic Network Process. USA: Springer.

Sapovadia, V. K. (2009). Good Corporate Governance: An Instrument For Wealth Maximization. In MBA Department of Saurashtra University Conference. Retrieved from https://papers.ssrn.com/sol3/papers. cfm?abstract-id $=955289$

Wanyama, D. W., \& Olweny, T. (2013). Effect of Corporate Governance on Financial Performance of Listed Insurance Firms in Kenya. Public Policy and Administration Research, 3(4).

Yusuf, T. O., \& Mobolajo, A. H. I. (2012). The Role of Islamic Micro Insurance in Economic Growth and Development: The Nigerian Experience: A Case Study of Al-Barakah Microfinance Bank, Lagos. International Journal of Business and Commerce, 1(10): 106-122. 